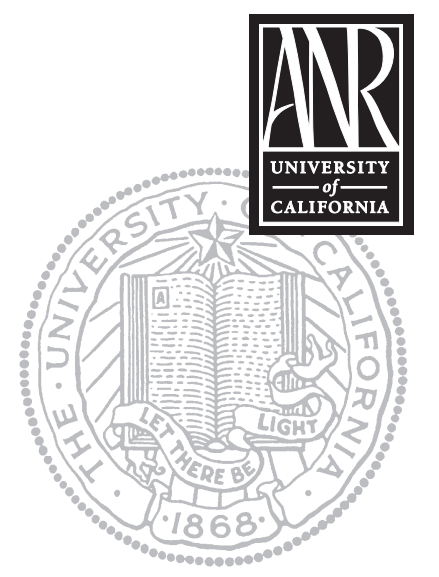

UNIVERSITY OF CALIFORNIA

Division of Agriculture and Natural Resources http://anrcatalog.ucdavis.edu

\title{
Beet and Swiss Chard Production in California
}

WAYNE L. SCHRADER, University of California Cooperative Extension Farm Advisor, San Diego County, and KEITH S. MAYBERRY, University of California Cooperative Extension Farm Advisor, Imperial County

\section{INTRODUCTION}

Beets (Beta vulgaris var. crassa) and Swiss chard (B. vulgaris var. cicla) are members of the Chenopodiaceae (goosefoot family). In addition to beets and Swiss chard, this family includes mangel-wurzel (B. vulgaris var. macrohiza), sugarbeets, and the weed lambsquarter (Chenopodium album). This publication covers table and fresh-market beets, processing beets, and Swiss chard (beets grown for their edible leaves). It does not cover mangel-wurzel (beets used as a livestock feed) or sugarbeets (beets grown for commercial sugar production).

Beets are thought to have been developed from the seabeet (Beta maritima), which is native to southern Europe. They have been cultivated since at least the third century A.D. and were fully developed as agronomic crops in the nineteenth century by German and French breeders.

Beets are used for bunched greens, bunched roots, beet roots, and by processors for several different products. The immature leaves of Swiss chard are harvested for braizing and salad mix; the mature leaves are harvested for bunching.

\section{TYPES AND CULTIVARS}

\section{Processing Beets}

Beets grown for processing are usually cylindrical in shape. Cylindrical beets offer greater uniformity and efficiency for sliced beet production, a major requirement for processors. Nonhybrids: Detroit Short Top, Ruby Ball, and Scarlet Supreme. Hybrid: Red Ace F1 (Cercospora-tolerant). Hybrid beets have the advantage of greater seedling vigor and improved top growth and resistance to certain diseases such as Cercospora. On the negative side, the vigor of hybrid beets may result in beet roots going "out of grade" (see "Harvesting and Handling," below) more quickly if harvest is delayed by poor weather or other reasons.

\section{Table Beets}

Table beets are also known as fresh-market beets. Red, round types: Detroit Stains, Ruby Queen (bulbs well when crowded). Hybrids: Red Ace F1, Hybrid Pacemaker III. For trial: Avenger F1, Big Red, Ivax (monogerm), Warrior F1. Bunching: Crosby's Greentop, Winter Keeper (long-season, for late-fall gardening use).

\section{Novelty Beets}

Some beets have unusual colors or shapes; these are known as novelty beets. Red elongated: Cylindra, Forono (half-long). Alternating red and white: Chiaggia. Yellow, round: Burpee Golden. Yellow elongated: Burpee Golden. White, round: Showhite, Albino. Most cylindrical varieties produce beets with an "earthy" taste, which has limited their adoption. 


\section{Spinach Beets}

Spinach beets (Beta vulgaris orientalis group) are table beets grown for their succulent leaves, which can be harvested over an extended period. The main variety is Burpee Red Ball.

\section{Swiss Chard}

Swiss chard is a beet grown for its edible leaves. It has large, well-developed petioles that may be green, red, or multicolored. Green petiole: Lucullus. Red petiole: Charlotte, Rhubarb Chard. Multicolored petiole: Bright Lights (red, yellow, white, orange, purple, pink).

\section{CROP ESTABLISHMENT}

Beets are grown as annuals. They are a cool-season crop that grows best when air temperatures are between $50^{\circ} \mathrm{F}$ and $64^{\circ} \mathrm{F}\left(10^{\circ} \mathrm{C}\right.$ and $\left.17.8^{\circ} \mathrm{C}\right)$. Higher temperatures lead to rapid growth and white rings in the interior of the beet root (zoning). The minimum soil temperature for beet seed germination is $41^{\circ} \mathrm{F}\left(5^{\circ} \mathrm{C}\right)$. Optimal temperatures for beet germination are $50^{\circ}$ to $86^{\circ} \mathrm{F}\left(10^{\circ}\right.$ to $\left.30^{\circ} \mathrm{C}\right)$. The maximum temperature for germination is $95^{\circ} \mathrm{F}\left(35^{\circ} \mathrm{C}\right)$. Beets require a cold period of 2 weeks at $39^{\circ}$ to $50^{\circ} \mathrm{F}\left(3.9^{\circ}\right.$ to $10^{\circ} \mathrm{C}$ ) to induce flowering. Beets will tolerate frosts and mild freezes.

Seeding or Planting. In the field, first plantings are usually made in March or April. Beets grown for processing can be planted from early May to late June. Sow seed every 2 or 3 weeks to provide a continuous supply of bunched beet roots. For fresh market beets, plants should be 2 to 3 inches ( 5 to $7.5 \mathrm{~cm}$ ) apart. Rows are normally 32 to 40 inches apart ( 81 to $102 \mathrm{~cm}$ ), and plants are usually spaced 12 to 24 inches $(30.5$ to $61 \mathrm{~cm}$ ) apart. Plant seed from 0.4 to 1 inch $(1$ to $2.5 \mathrm{~cm})$ deep. It normally takes 8 to 10 pounds of seed to plant one acre $(9.0$ to $11.2 \mathrm{~kg} / \mathrm{ha})$. Table beet seed numbers approximately 1,600 per ounce $(1,700$ per $30 \mathrm{~g})$. Swiss chard is usually planted on 40-inch $(102-\mathrm{cm})$ beds with a spacing of 9 to 12 inches $(23$ to $30.5 \mathrm{~cm}$ ) between plants. It takes about 6 to 8 pounds of seed to plant one acre (6.7 to 9.0 $\mathrm{kg} / \mathrm{ha}$ ).

Small (baby) beets intended for whole pack and pickled packs may be produced by reducing the spacing between rows to about 10 to 15 inches $(25$ to $38 \mathrm{~cm}$ ) and maintaining about 30 to 35 plants per foot (100 to 115 per meter) of row. More commonly, baby beets are sorted out of the regularly harvested product in normal processing operations.

\section{SOILS}

Beets prefer deep, friable, well-drained soils such as sandy loam, silt loam, or muck. They may be grown on heavier (more clayey) soils, but harvesting is more difficult and root growth may be impaired. High levels of organic matter in the soil are desirable and will help ensure an adequate moisture supply. The beet has a large root system that extends down in the soil about 3 feet $(1 \mathrm{~m})$ or more unless root growth is restricted.

Uniform soil moisture is essential for best quality. Rotate crops to avoid damping-off and root rot diseases. Beets are sensitive to damping-off on soils that may flood or have poor aeration. Adjust soil $\mathrm{pH}$ to 6.0 or higher for maximum yields. Follow soil test recommendations for liming rates. Fields in which processing beets are to be planted are usually tested by the processor for residues of chlorinated hydrocarbons and rejected if these residues are found to be unacceptable. 


\section{FERTILIZERS}

Preplant soil tests are the most accurate guides to fertilizer requirements. Good management practices are essential if optimal fertilizer responses are to be realized in beets. These practices include use of recommended varieties, selection of appropriate soils, good weed control, disease and insect control, good seed bed preparation, proper seeding methods, and timely harvest.

Because of the influence of soil type, climatic conditions, and other cultural practices, crop response from fertilizer may not always be accurately predicted. Soil test results, field experience, and knowledge of specific crop requirements help determine the nutrients needed and the rate of application.

Recommended soil sampling procedures should be followed in order to estimate fertilizer needs. The University of California Cooperative Extension (UCCE) advisor in your county can provide you with soil sampling instructions and information sheets. UCCE offices do not perform laboratory tests.

\section{Nitrogen}

Application of 150 to 200 pounds per acre (168 to $224 \mathrm{~kg} / \mathrm{ha}$ ) of elemental nitrogen (N) is recommended. The lower rates of nitrogen should be used following a good legume crop such as alfalfa or red clover. The higher nitrogen rates should be used following grain or grass seed. Broadcast the nitrogen before planting or apply up to one-half of the nitrogen as an early-season top dressing. Nitrogen is important in maintaining the top growth needed for efficient harvest, since traditional harvesting equipment handles beets by their tops.

\section{Phosphorous}

Phosphorus $(\mathrm{P})$ is necessary for vigorous early seedling growth that may reduce damage from damping-off. Band 50 to 70 pounds per acre (56 to $78 \mathrm{~kg} / \mathrm{ha}$ ) of phosphate $\left(\mathrm{P}_{2} \mathrm{O}_{5}\right)$ as superphosphate or triple superphosphate fertilizer 1 inch $(2.5 \mathrm{~cm})$ directly beneath the seed. Warning: Severe seedling burn can result if nitrogen-phosphorus mixtures or fertilizers containing potassium or boron are banded directly beneath the

Table 1. Phosphorus application rates for beets

\begin{tabular}{|c|c|c|}
\hline & \multicolumn{2}{|c|}{ Apply this amount of phosphate $\left(\mathrm{P}_{2} \mathrm{O}_{5}\right)$} \\
\hline If the soil test for P reads (ppm) & lb/acre & $\mathrm{kg} / \mathrm{ha}$ \\
\hline $0-25$ & $120-150$ & $134.4-168$ \\
\hline $25-50$ & $70-120$ & $78.4-134.4$ \\
\hline 50 & $50-70$ & $56-78.4$ \\
\hline
\end{tabular}

Table 2. Potassium application rates for beets

\begin{tabular}{|c|c|c|}
\hline & \multicolumn{2}{|c|}{ Apply this amount of potash $\left(\mathrm{K}_{2} \mathrm{O}\right)$} \\
\hline If the soil test for K reads $(\mathrm{ppm})$ & $\mathrm{lb} / \mathrm{acre}$ & $\mathrm{kg} / \mathrm{ha}$ \\
\hline $0-75$ & $120-150$ & $134.4-168$ \\
\hline $75-150$ & $80-120$ & $89.6-134.4$ \\
\hline $150-225$ & $60-80$ & $67.2-89.6$ \\
\hline 225 & none & none \\
\hline
\end{tabular}
seed. Broadcast and work the remainder of the phosphorus into the seedbed before seeding as indicated in table 1.

\section{Potassium}

Broadcast potassium in the form of potash $\left(\mathrm{K}_{2} \mathrm{O}\right)$ and work it into the soil before planting. Use the rates indicated in table 2.

\section{Sulfur}

Plants absorb sulfur $(\mathrm{S})$ in the form of sulfate $\left(\mathrm{SO}_{4}\right)$. Fertilizer materials supply sulfur in the form of sulfate and elemental sulfur. Elemental sulfur must be converted to sulfate in the soil before the sulfur becomes available to plants. The conversion of elemental sulfur to sulfate is usually rapid for finely ground (less than 40 mesh) material in warm, moist soil. The sulfur requirements of table beets can be provided by one of the following: 
- applying 15 to 20 pounds per acre (16.8 to $22.4 \mathrm{~kg} / \mathrm{ha}$ ) of sulfur in the form of sulfate at planting time; or

- applying 30 to 40 pounds per acre (33.6 to $44.8 \mathrm{~kg} / \mathrm{ha}$ ) of sulfur as finely ground elemental sulfur the preceding year; or

- applying more coarsely ground elemental sulfur at higher rates and less frequently.

\section{Magnesium}

Applications of 10 to 15 pounds per acre (11.2 to $16.8 \mathrm{~kg} / \mathrm{ha}$ ) of magnesium (Mg) are suggested when the soil test value for magnesium is below $1.0 \mathrm{meq} \mathrm{Mg} / 100 \mathrm{~g}$ of soil. Magnesium can also be supplied in dolomite, a liming material that reduces soil acidity with about the same degree of effectiveness as ground limestone (see "Lime," below). If used, dolomite should be mixed into the seedbed several weeks before seeding.

\section{Boron}

Boron deficiency (canker) in table beets has been severe in some areas of California. In these areas, foliar applications of water-soluble boron (B) materials are needed in addition to soil application. Lack of moisture aggravates boron deficiency. Boron should not be banded; instead, it should be applied evenly to the field. If all required boron is applied as a single preplant broadcast treatment, 8 to 10 pounds per acre (9.0 to $11.2 \mathrm{~kg} / \mathrm{ha}$ ) of elemental boron is usually used. However, rather than this single application, it is recommended that boron be applied in one of the following programs:

- Preplant treatment: Apply 3 to 5 pounds per acre (3.4 to $5.6 \mathrm{~kg} / \mathrm{ha})$ of boron (broadcast and disked in). This rate has been adequate where canker has not been severe.

- Combination treatment: This is to be used where canker is severe or where beets are held for late harvest. Make a preplant application of 3 to 5 pounds per acre (3.4 to $5.6 \mathrm{~kg} / \mathrm{ha}$ ) of boron (broadcast and disked in) plus two to three foliar applications of water-soluble boron materials. For foliar applications, use 1 pound per acre $(1.1 \mathrm{~kg} / \mathrm{ha}$ ) of boron in 50 to 100 gallons (189 to 378.51 ) of water. Apply at the time of enlargement (bulbing) of beet roots and when beet roots are 1.5 to 2 inches $(4$ to $5 \mathrm{~cm}$ ) in diameter. Make an additional application 10 to 14 days later.

Table 3. Lime applications for beets

\begin{tabular}{|c|c|c|}
\hline & \multicolumn{2}{|c|}{ Apply this amount of lime } \\
\hline If the buffer test for lime reads & ton/acre & metric ton/ha \\
\hline$<5.2$ & $4-5$ & $9.0-11.2$ \\
\hline $5.2-5.7$ & $3-4$ & $6.7-9.0$ \\
\hline $5.7-6.0$ & $2-3$ & $4.5-6.7$ \\
\hline $6.0-6.3$ & $1-2$ & $2.2-4.5$ \\
\hline$>6.3$ & none & none \\
\hline
\end{tabular}

Table 4. Beet water use

Total seasonal evapotranspiration

Peak evapotranspiration rate

Maximum allowable water depletion

Critical moisture deficit period
15.1 in $(38.4 \mathrm{~cm})$

$0.21 \mathrm{in} /$ day $(0.53 \mathrm{~cm} /$ day $)$

$50 \%$

seed germination, root expansion

\section{Lime}

Table beets are less tolerant of soil acidity than bush beans or sweet corn. Lime applications should be made when the soil $\mathrm{pH}$ is 5.8 or below, or when calcium levels are below $7 \mathrm{meq} \mathrm{Ca} / \mathrm{l00g}$ of soil (see table 3 ). The liming rate given in table 3 is based on 100score lime. Lime should be mixed into the soil at least several weeks before planting, preferably during the previous fall. A lime application is effective for several years.

\section{IRRIGATION}

Irrigate beets carefully, especially early in the season so as to avoid overwatering (see table 4). Waterlogging can cause beet leaves to turn red and cause plants to stop growing for a time. A total of 12 to 14 
inches (30.5 to $35.5 \mathrm{~cm}$ ) of water may be needed in California production areas. Soil type does not affect the amount of total water needed but does affect frequency of water application: lighter soils need more frequent water applications with less water applied per application. Excessive irrigation or moisture early in the growing season can encourage damping-off and other seedling disorders. A lack of water, however, can aggravate boron deficiency.

Moisture management in beets is especially important during stand establishment, the early growth stage, and root expansion. Since small beet seed are unable to emerge when surface crusting occurs, irrigation during the preemergence period should strive to maintain a loose soil surface. This often requires frequent, light irrigations. Conversely, deep, excessive irrigation, which causes anaerobic soil conditions, can encourage damping-off of emerging seedlings and temporary cessation of growth in young plants. In the remainder of the growing season, available soil moisture should not be depleted by more than 50 percent. Because beet roots develop most of their size in the last half of their growth period, irrigation is especially critical during this time. Water deficit during this period will have the greatest negative impact on yields. A balance must be struck, however, between maintaining adequate moisture while minimizing wetness in the canopy that promotes diseases caused by Alternaria, Cercospora, and Ramularia spp. fungi. During the last half of the growing period, irrigate only early in the day to allow for rapid canopy drying whenever possible.

The peak water use for beets, which occurs in July, is approximately 0.21 inches $(0.53 \mathrm{~cm})$ per day. On most soils, weekly irrigation during the peak is adequate. With sandy and sandy loam soils, however, irrigation may be required as frequently as every 3 to 4 days.

\section{PEST MANAGEMENT}

Refer to the University of California IPM pest management guidelines at http://www.ipm.ucdavis.edu for more information on insect, disease, and weed control for beets and Swiss chard.

\section{PHYSIOLOGICAL DISORDERS}

The main physiological disorder of table beet roots is zoning, in which alternating red and pale bands appear in a root cross-section. The pale areas do not accumulate the deep red anthocyanin pigment normally associated with red beets, and the rings may remain nearly colorless or white. This disorder is most pronounced in hot weather and when table beets are grown in climates to which they are not well adapted. Most commercial beet production is in Oregon, New York, and Wisconsin, or in more southerly states during the cooler parts of the year. Contributing factors to zoning are high temperature and variety. Moderately high temperatures and cool nights favor good pigment development and decrease the incidence of zoning.

\section{HARVESTING AND HANDLING}

\section{Timing}

Table beets generally reach market size in 42 to 56 days; round beets require 60 to 70 days. Cyllindrical beets for processing require 70 to 80 days, depending on planting date, sizes desired, and growth season.

Beet roots for processing and fresh market are harvested mainly from July 15 to the end of October in the cooler areas of California. The prime harvest period is 
between August 1 and October 1. Individual fields may be harvested over a severalweek period.

Follow processor recommendations for the timing of harvest. Beets are graded according to their diameter: Grade 1 beets are 1 to 15/8 inches; Grade 2 are over 15/8 to $2 \frac{5}{8}$ inches; and Grade 3 are over $2 \frac{5}{8}$ to $3 \frac{1}{2}$ or 4 inches, depending on processor requirements. Beets are usually harvested when their size distribution approaches 25 percent Grade 1, 60 percent Grade 2, and 15 percent Grade 3 paid weight, with about 1 percent culls. These grade distributions vary from year to year according to the type of product being processed and seasonal variations. In general, the percentage of Grade 2 changes very little, with most of the yearly or seasonal range differences occurring in Grade 1 and Grade 3 beets.

\section{Yield}

The yield of processing beets averages approximately 18 tons per acre $(39.6 \mathrm{~T} / \mathrm{ha})$, with good yields approximately 25 tons per acre ( $55 \mathrm{~T} / \mathrm{ha})$. Fresh market beets are reported to average 140 hundredweight per acre (15.7 T/ha,) with good yields of 200 hundredweight per acre (22.4 T/ha).

\section{Equipment}

Beets are usually harvested and topped with tractor-pulled or self-propelled machines that are locally custom-built. However, beets can also be harvested with single- or multiple-row harvesters that are custom built by Krier Engineering of Modesto, California; contact Mr. Alex Krier at 800-344-3218 for more information.

Because of the slowness and the high maintenance requirements of Scott-Viner type harvesters, table beet growers in Oregon have begun to use multiple-row diggers similar to potato harvesters. This requires that the tops be removed before digging. Top removal is done in two steps: a flail is used to remove leaf blades and as much top as possible without damage to the roots, followed by a sugar beet-topping device with three drums of rubber-fingered flails. The latter removes the remaining leaf blades to within an inch or two of the beet root. Roots are harvested with an AMAC harvester (see below) that lifts the beets, accomplishes more topping with a hedgehog belt, and loads the beets into bulk trailers or trucks for transport to the processor. It is important to consider soil type and weed control and to experiment with the proper interval between toping and digging to allow for the harvest of clean product. Beets are hauled from the field to the processor in loads of 10 to 14 tons (9.1 to $12.7 \mathrm{~T}$ ) in double-axle dump trucks.

Custom-built beet and carrot harvesters are available from:

- AMAC Inc., a Dutch company represented by KPR Inc., POB 608, 375 West Ave. D, Wendell, ID 83355-0608, phone 208-536-6601, FAX 208-536-6695, Email info@KprIncorp.com, Web site www.KprIncorp.com

- Asa-Lift, a Danish company represented by Miller Farms, Hancock, WI, phone 715-249-5160, FAX 715-249-5860, E-mail MillerFM@uniontel.net

- Everett Bros. Engineering Ltd., a British company, USA Tel/FAX 407-396-7515, E-mail sales@everettbros.btinternet.com, Web site www.everett-bros-eng.com

- Univerco Hydraulique (1978) Inc., a Canadian company, 713 Rte. 219, Napierville, PQ, J0J 1L0, Canada, phone 800-663-8423, FAX 514-245-0068. 


\section{STORAGE}

Beet roots should be reasonably dry and free of soil for best storage; they should also be topped and sorted to remove all those with disease or mechanical injury. Although processing beets are often stockpiled for several days without serious deterioration, this practice is not usually recommended. For longer storage, proper storage facilities are needed. Beets should be stored at $32^{\circ} \mathrm{F}\left(0^{\circ} \mathrm{C}\right)$ and relative humidity of 98 to 100 percent. Like other root crops, beets are well adapted to storage. Topped beets stored at $32^{\circ} \mathrm{F}\left(0^{\circ} \mathrm{C}\right)$ can be expected to keep 4 to 6 months under suitable storage conditions. Swiss chard should be stored at $32^{\circ} \mathrm{F}\left(0^{\circ} \mathrm{C}\right)$ and 95 to 100 percent relative humidity. The approximate storage life for chard is 10 to 14 days. Chard should not be stored with ethylene-producing vegetables.

Either cold storage or cool-cellar storage is suitable for beets, provided the humidity is kept sufficiently high to prevent shriveling. Cellar storage temperatures fluctuate and are often higher than $32^{\circ} \mathrm{F}\left(0^{\circ} \mathrm{C}\right)$, so the period of successful storage will be comparatively shorter. The temperature in cellar storage should not exceed $45^{\circ} \mathrm{F}$ $\left(7.2^{\circ} \mathrm{C}\right)$ to minimize sprouting and decay. Because beets wilt readily from loss of water, they should be kept where the humidity is sufficiently high to prevent excessive evaporation. Small beets soften and shrivel earlier than larger ones.

Beets should not be stored in large bulk. They should be stored in well-ventilated containers, such as ventilated bin boxes or slatted crates, to help dissipate respiratory heat. Increasing the carbon dioxide level in beet storages 5 to 10 percent has been shown to increase fungal spoilage.

Bunched beets are much more perishable than topped beets, but they can be stored at $32^{\circ} \mathrm{F}\left(0^{\circ} \mathrm{C}\right)$ for 10 to 14 days. Storing them in crushed ice will help keep the bunched beets cold, especially if refrigeration is not available.

Beet greens and and chard are handled like spinach. Because of their perishability, they should be held as close to $32^{\circ} \mathrm{F}\left(0^{\circ} \mathrm{C}\right)$ as possible. At this temperature, they can be held for 10 to 14 days. Relative humidity of at least 95 percent is desirable to prevent wilting. Air circulation should be adequate to remove heat of respiration, but rapid air circulation speeds transpiration and wilting. Satisfactory precooling is accomplished by vacuum cooling or hydrocooling. These leafy greens are commonly shipped with package and top ice to maintain freshness. Research has shown that kale packed in polyethylene-lined crates and protected by crushed ice keeps in excellent condition for 3 weeks at $32^{\circ} \mathrm{F}\left(0^{\circ} \mathrm{C}\right)$ but only 1 week at $40^{\circ} \mathrm{F}\left(4.4^{\circ} \mathrm{C}\right)$ and 3 days at $50^{\circ} \mathrm{F}\left(10^{\circ} \mathrm{C}\right)$. Vitamin content and quality are retained better when wilting is prevented.

\section{PACKAGING}

Fresh-market beets are usually bunched by hand and are packaged in 35-pound halfcrates or 32-pound $4 / 5$ bushel crates. Beets intended for processing are harvested as needed into self-unloading trucks, bulk truck bodies, or trailers for immediate transport and processing. Chard is boxed in 32 pound crates that have holes in them to keep the chard fresh. 
FOR MORE INFORMATION

You'll find more information on beet and chard in the following ANR sources:

California Master Gardener Handbook. Publication 3382, 2002.

Postharvest Technology of Horticultural Crops, Third Edition, Publication 3311, 2002.

Visit our online catalog at http://anrcatalog.ucdavis.edu. You can also place orders by mail, phone, or FAX, or request a printed catalog of publications, slide sets, CD-ROMs, and videos from

University of California

Agriculture and Natural Resources

Communication Services

6701 San Pablo Avenue, 2nd Floor

Oakland, California 94608-1239

Telephone: (800) 994-8849 or (510) 642-2431

FAX: (510) 643-5470

E-mail inquiries: danrcs@ucdavis.edu

An electronic version of this publication is available on the ANR Communication Services Web site at http://anrcatalog.ucdavis.edu.

\section{Publication 8096}

(C) 2003 by the Regents of the University of California, Division of Agriculture and Natural Resources. All rights reserved.

The University of California prohibits discrimination against or harassment of any person employed by or seeking employment with the University on the basis of race, color, national origin, religion, sex, physical or mental disability, medical condition (cancer-related or genetic characteristics), ancestry, marital status, age, sexual orientation, citizenship, or status as a covered veteran (special disabled veteran, Vietnam-era veteran or any other veteran who served on active duty during a war or in a campaign or expedition for which a campaign badge has been authorized).

University Policy is intended to be consistent with the provisions of applicable State and Federal laws.

Inquiries regarding the University's nondiscrimination policies may be directed to the Affirmative Action/Staff Personnel Services Director, University of California, Agriculture and Natural Resources, 300 Lakeside Drive, 6th Floor, Oakland, CA 94612-3550 (510) 987-0096. For information about obtaining this publication, call (800) 994-8849. For information about downloading, call (530) 754-5112.

pr-2/03-SB/CR

ISBN 978-1-60107-270-2

This publication has been anonymously peer reviewed for technical accuracy by University of California scientists and other qualified professionals. This review process was managed by the ANR Associate Editor for Vegetable Crops. 